\title{
Characterizing microbial communities dedicated for conversion of coal to methane in situ and $e x$ situ
}

\author{
Ji Zhang ${ }^{1}$, Yanna Liang ${ }^{1}$, Rohit Pandey $^{2}$, Satya Harpalani ${ }^{2}$ \\ ${ }^{1}$ Department of Civil \& Environmental Engineering, 1230 Lincoln Dr., Southern Illinois \\ University Carbondale, Carbondale, IL 62901, USA \\ ${ }^{2}$ Department of Mining and Mineral Resources Engineering, 1230 Lincoln Dr., Southern Illinois \\ University Carbondale, Carbondale, IL 62901, USA \\ * Corresponding author phone: 618-453-7808; fax: 618-453-3044 \\ E-mail: liangy@siu.edu
}

\begin{abstract}
To enhance methane production in situ in bituminous coal seams, distribution of microorganisms in the formation water collected from a coalbed methane well was investigated. Based on next generation DNA sequencing, both bacteria (231species) and archaea (33 species) were identified. Among the bacterial kingdom, polymer-degrading, benzoate, fatty acid and sugar utilizing bacteria were dominant. Among the archaea domain, the major methanogens $(89.8 \%)$ belonged to the order of Methanobacteriales which are hydrogenotrophic. To develop a microbial consortium for ex situ coal bioconversion, the original microbial community was adapted to ground coals for five months in a laboratory environment. DNA sequencing revealed the presence of 185 bacteria species and nine archaea species which were dramatically different from those in the original formation water. In particular, the majority $(90.4 \%)$ of methanogens were under the order of Methanomicrobiales. To increase methane production, two nutrient solutions were tested. Solution \#2 which targeted methanogens provided a methane yield of 111
\end{abstract}


$\mathrm{ft}^{3} /$ ton in 20 days, which translated to a $5.6 \mathrm{ft}^{3} /$ ton-day. In addition, the adapted consortium was found to be aerotolerant.

Keywords: bituminous coal, bioconversion, methane, formation water, microbial community, next-generating sequencing

\section{Introduction}

It is believed that an option for reducing $\mathrm{CO}_{2}$ emissions is to replace coal-fired power plants with natural gas-fired ones. According to US Energy Information Administration's estimation, burning natural gas releases 1.21 pounds of $\mathrm{CO}_{2}$ per $\mathrm{kWh}$, which is approximately $60 \%$ of 2.07-2.17 pounds of $\mathrm{CO}_{2}$ per $\mathrm{kWh}$ emitted from coal (bituminous to lignite). In addition, burning natural gas emits less sulfur, mercury and particulate matter than coal (Agyarko and Mansoori, 2013). Furthermore, recent development in high-temperature and more efficient natural gas combustion turbines by different manufacturers make natural gas-fired power plants an even better option. Finally, combusting natural gas produces a clean stream of $\mathrm{CO}_{2}$, ready for storage and/or utilization. Thus, during recent decades, searching for unconventional natural gas has been on the rise world-wide.

Unconventional gas mainly includes three categories: 1) shale gas, which is trapped in fine grained sedimentary rock called shale, requiring "hydraulic fracturing" technology to be produced; 2) tight gas, which is embedded in relatively impermeable hard rock, limestone or sandstone, sometimes with quantified limit of permeability; and 3) coalbed methane (CBM), which is contained in coal seams and adsorbed in the solid matrix of coal (McGlade et al., 2013). While production of shale gas increased ten-fold between 2006 and 2010, considering the extremely high uncertainty, it is still far from clear whether the expectations of huge and easily 
recoverable shale gas can be ultimately fulfilled (Berman, 2010; Berman and Pittinger, 2011). In addition, the shale gas extraction process, "fracking", has led to heated debates regarding its environmental impacts. For example, first, fracking necessitates high-pressure injection of water, chemicals and sand into shale formations to create and open fractures that enable hydrocarbons to flow. This practice leaves millions of gallons of water, mixed with additives, in the ground, which could result in pollution of underground aquifers; second, it is claimed that shale gas emissions of greenhouse gases are even higher than the conventional natural gas emissions, and may be equal or higher than the emissions caused by using coal or petroleum (Howarth et al., 2011).

Thus, considering the significant uncertainty, high cost and negative environmental impact associated with shale gas and difficulties in extracting tight gas, CBM is the best option among the three. CBM or microbially enhanced CBM (MECBM) through microbial processes appears to be favored in lower-rank coals, such as lignite or subbituminous coal, which have high permeability and highly branched compounds that may be accessible to microorganisms. Typical examples include, but are not limited to: Powder River Basin coals (Ayers, 2002; Flores et al., 2008; Ulrich and Bower, 2008), San Juan Basin coals (Scott et al., 1994) and south Sydney Basin coals (Faiz and Hendry, 2006). In the US, commercial production of CBM is mainly in states west of the Mississippi river, where $83.7 \%$ of coal is either subbituminous or lignite. For states that are east of the Mississippi river, where $96.4 \%$ of coal is bituminous (EIA), CBM has not been very successful. For example, State of Illinois has the largest overall as well as strippable bituminous coal reserves in the nation (Agyarko and Mansoori, 2013) but very limited CBM production due to low gas production rates. To solve this issue, the first objective of this study sought to understand the methane producing potential of an Illinois coal seam through 
elucidating structure of the microbial community in the formation water. Accomplishment of this objective would open doors for enhancing methane yield from this site.

Besides CBM, where methane is released in situ, methane can also be produced from mined out coals through surface mining and coal waste. Using coal waste as an example, about 55 million tons of waste coals are generated annually in US (Tillman and Harding, 2004). For the state of Illinois, around 5 million tons of mined coals are fine and/or ultrafine coal, and considered waste. This translates into an approximately $\$ 250 \mathrm{M}$ loss to the Illinois coal industry (Chen et al., 2003). In addition to economic loss, coal wastes are either piled up at mine sites or dumped in ponds where the environmental risk is extremely high but difficult to assess.

In order to address the coal waste issue and utilize mined out coals for methane production instead of burning for electricity, the second and third objective of this investigation aimed to develop/characterize an adapted microbial consortium that can be used for bioconversion of coal to methane ex situ and evaluate the effect of biostimulation on methane yield from bituminous coals collected from the Illinois basin, respectively. Keeping potential future large scale operation in mind, the adapted microbial consortium was intentionally exposed to air to select those that are aerotolerant. Therefore, this is the first study to report: 1) detailed population distribution of a microbial community originally in the Illinois basin; 2) microbial structure of an adapted consortium that tolerate air exposure and is still active in methane production from coal; and 3) methane yield from Illinois coals operated ex situ. The major advantage of using the adapted consortium is that the delicate, expensive, cumbersome and strict anaerobic environment for handling anaerobic cultures can be avoided. The developed microbial consortium can thus be used ex situ in industrial scale bioreactors or injected into coal seams where indigenous community capable of converting coal to methane is not available. Such coal 
seams have been reported for Sydney and Port Philip basins in Australia (Li et al., 2008).

\section{Materials and Methods}

\subsection{Coal samples}

Chunks of coals were collected from a coal mining site $\left(38.2461^{\circ} \mathrm{N}, 89.7528^{\circ} \mathrm{W}, 450-500\right.$ feet $)$ in Washington County, Illinois (Fig. 1). This coal mine is part of the Herrin Seam, \# 6 of the Illinois basin. We chose to study coals from this seam considering that the Herrin seam is one of the two regions in the Illinois Basin where most of the mining activity is currently taking place and a significant amount of methane extraction is currently underway. This seam is known to contain high volatile B bituminous coal (Korose and Elrick, 2010). Results from proximate and ultimate analyses of the coals used in this study also confirmed the same coal rank (Table 1). To simulate mined out coal or coal waste, the collected coal samples were not kept in a strict anaerobic chamber, but instead immersed in water in a bucket at room temperature. Prior to testing, the coal was ground and only the portion that passed through a 40 mesh $(<0.42 \mathrm{~mm})$ screen was kept in ziploc bags and maintained in a humidity chamber to avoid water loss.

\subsection{Microbial community in the formation water}

\subsubsection{Genomic DNA extraction}

Formation water was obtained from a CBM operation in southern Illinois. Water was retrieved from a depth of $\sim 850$ feet. It was sealed tight in five-gallon containers and brought to our laboratories, where it was immediately transferred to smaller containers and stored in a refrigerator. To select aerotolerant microorganisms, reducing agents, such as sodium sulfide was intentionally not added.

To extract genomic DNA from the retrieved water, one liter of water sample was passed through a membrane filter $(90 \mathrm{~mm}, 0.22 \mu \mathrm{m})$. The formation water contained suspended coal 
particles. In order not to lose those microorganisms attached to coal particles, all that were retained on the filter were then processed for DNA extraction using Powerwater DNA extraction kit (Mo Bio, Carlsbad, CA, USA). Following extraction, DNA samples were quantified and evaluated through use of a Nanodrop spectrophotometer. Three DNA samples with excellent quality ( $\mathrm{A}_{260} / \mathrm{A}_{280}$ : 1.8-2.0) and high concentrations (30-50 ng/ $\left.\mu \mathrm{l}\right)$ were subject to sequencing.

\subsubsection{DNA sequencing}

For each sample, three different assays were conducted. To understand the overall diversity of the microbial population, the 16S rRNA gene V4 variable region PCR primers 515/806 (Caporaso et al., 2011) were used. Single-step PCR using the HotStarTaq Plus Master Mix Kit (Qiagen, Valencia, CA, USA) was performed under these conditions: $94^{\circ} \mathrm{C}$ for 3 minutes, 28 cycles of $94^{\circ} \mathrm{C}$ for 30 seconds, $53^{\circ} \mathrm{C}$ for 40 seconds and $72^{\circ} \mathrm{C}$ for 1 minute, and a final elongation step at $72^{\circ} \mathrm{C}$ for 5 minutes. Sequencing was conducted at Molecular Research (Shallowater, TX, USA) on an Ion Torrent PGM following the manufacturer's guidelines. Sequence data (15-20,000 reads/assay) were processed using a proprietary analysis pipeline (Molecular Research, Shallowater, TX, USA). In summary, barcodes, primers, sequences $<150$ bp, and sequences with ambiguous base calls and with homopolymer runs exceeding 6 bp were removed. Following the removal, sequences were denoised, chimeras were removed and operational taxonomic units (OTUs) were generated. OTUs were defined by clustering at $3 \%$ divergence (97\% similarity) (Dowd et al., 2008; Edgar, 2010). Final OTUs were taxonomically classified using BLASTn against a curated GreenGenes database (DeSantis et al., 2006) and compiled into each taxonomic level into both "counts" and "percentage" files. Counts files contain the actual number of sequences while the percent files contain the relative (proportion) percentage of sequences within each sample that map to the designated taxonomic classification. 
To elucidate distribution of eubacterial species, the $16 \mathrm{~S}$ eubacterial primers $27 \mathrm{~F}$ (AGRGTTTGATCMTGGCTCAG) and 519 R (GTNTTACNGCGGCKGCTG) were used for amplifying the 492 bp region of $16 \mathrm{~S}$ rRNA genes through 454 pyrosequencing. To understand diversity within the archaea kingdom, in particular, methane-producing methanogens, a primer pair of 86F (GCTCAGTAACACGTGG) and 448R (GCGGCGGCTGGCACC) was adopted for 454 pyrosequencing as well. Both 454 sequencing provided 3,000 reads/assay. PCR conditions were the same as explained above. Following PCR, all amplicon products from different samples were mixed in equal concentrations and purified using Agencourt Ampure beads (Agencourt Bioscience Corporation, MA, USA). Samples were sequenced by Molecular Research (Shallowater, TX, USA) utilizing Roche 454 FLX titanium instruments and reagents following manufacturer's guidelines. Sequencing data were processed and analyzed in the same way as detailed above.

\subsection{Converting coal to methane}

Microorganisms that were initially in formation water and collected on membrane filters were added to $10 \mathrm{~g}$ of ground coal $(<40 \mathrm{mesh})$ in three different media. The first medium was a standard Tanner medium dedicated for cultivating anaerobic bacterial strains (Tanner et al., 2007). The second medium was a MS medium for growing methanogens (Bonin and Boone, 2006). The third one was formation water depleted with microbes after filtration. All media were autoclaved at $121^{\circ} \mathrm{C}$ for $30 \mathrm{~min}$ before use.

Once cells were added to a serum bottle $(100 \mathrm{~mL})$ containing $10 \mathrm{~g}$ of coal and $50 \mathrm{~mL}$ of solution, the bottle was closed with a butyl rubber stopper and sealed by an aluminum crimp. Each bottle was purged with $\mathrm{N}_{2}$ for around 30 min to drive out air. After the entire content in each bottle appeared to be colorless, all bottles were kept in dark at $28^{\circ} \mathrm{C}$. To test effects from 
different medium, nutrient solution \# 2 and \# 3 were investigated at their original strength (100\%) with two replicates. For medium \# 1 and \# 2, two other concentrations, $20 \%$ and $50 \%$ of the initial strength were also studied. Dilution to these lower concentrations was made by adding deionized and distilled water (DDW). At different time points, the headspace was sampled to obtain concentrations of methane and $\mathrm{CO}_{2}$ by using a gas chromatograph (GC) as detailed below.

After 65 days of cultivation, cells in the microcosms with $100 \%$ medium \#2 were used to inoculate $10 \mathrm{~g}$ of fresh coal samples. Briefly, five $\mathrm{mL}$ of inoculum was added to $10 \mathrm{~g}$ of coal with $45 \mathrm{~mL}$ of medium \#2. After setting up four microcosms under the same conditions, two bottles were purged with $\mathrm{N}_{2}$ while the other two were not. All microcosms were maintained at $28^{\circ} \mathrm{C}$ in darkness. On day 10,20 and 30 , the headspace gas was tested for methane and $\mathrm{CO}_{2}$ concentrations using $\mathrm{GC}$ as detailed below.

2.4. DNA sequencing of the adapted microbial consortium, coal, and coal residue

Following 30-day cultivation of the aforementioned microcosms, the entire content was allowed to settle. The liquid phase was referred to as the adapted consortium, the solid portion was named as coal residue. The liquid phase was withdrawn and centrifuged at 5,000 $\mathrm{g}$ for 10 min to collect suspended cells. These cells, coal residue (2.56 g, wet weight) and coal (1.5 g) that was used in the above experiments were subjected to DNA extraction separately through use of the Powerwater DNA extraction kit with a slightly modified procedure to fit into our application. All extracted DNA samples were handled in the same way as described above for the original community in the formation water. Three sequencing assays were performed on the three sets of samples using the same procedures described above.

\subsection{Analysis}


A Shimadzu gas chromatograph (GC) 17A with a Flame Ionizing Detector (FID) was used to measure methane and $\mathrm{CO}_{2}$ content in headspace of serum bottles. Briefly, a $50 \mathrm{uL}$ aseptic syringe connected to a sterile 25 gauge needle was used to withdraw and inject a $25 \mathrm{uL}$ of gas sample to a $60 \mathrm{~m} * 0.53 \mathrm{~mm}$ RT-Msieve 5A molecular sieve capillary column (Restek Corp., Bellefonte, PA, USA). The carrier gas (Argon) flow rate was set at $10.1 \mathrm{~mL} / \mathrm{min}$ with a velocity of $55 \mathrm{~cm} / \mathrm{sec}$. The isothermal zone temperatures for the injector and detector were set at $75^{\circ} \mathrm{C}$ and $310^{\circ} \mathrm{C}$, respectively. The retention time for methane was 4.73 min and that for $\mathrm{CO}_{2}$ was 6.71 min. Calibration curves for methane and $\mathrm{CO}_{2}$ were established using standard gases (Air Liquide, Plumsteadville, PA, USA).

\section{Results and Discussions}

3.1. DNA sequencing: the original microbial community vs. the adapted consortium

Producing methane from coal through microbial processes requires the collective actions of microorganisms comprising three major metabolic groups: 1) hydrolytic and fermentative bacteria; 2) acetogenic bacteria, and 3) methanogenic archaea. During the initial stage of gas production, complex organic compounds in coals are decomposed to simpler molecules, such as, acetate, long chain fatty acids, $\mathrm{CO}_{2}, \mathrm{H}_{2}, \mathrm{CH}_{4}$, and $\mathrm{HS}^{-}$by fermentative anaerobes. Fatty acids, alcohols, and some aromatic and amino acids are then converted to $\mathrm{H}_{2}, \mathrm{CO}_{2}$, and acetate by $\mathrm{H}_{2}$ producing acetogens while $\mathrm{H}_{2}$-using acetogic bacteria consume $\mathrm{H}_{2}$ and $\mathrm{CO}_{2}$ to produce more acetate. Finally, simple molecules are transformed to $\mathrm{CH}_{4}$ by methanogens belonging to the domain of Archaea (Faiz and Hendry, 2006).

For all samples sent for sequencing, the results among three replicates were basically the same. Thus, the DNA extraction process we adopted is highly reliable and repeatable. Through the diversity assay using the 515/806 primer pair, it was revealed that (Fig. 2): 1) the formation 
water contained $44 \%$ of bacterial strains and $56 \%$ of archaea; 2) DNA extracted from the coal samples that were used in our studies comprised $92.6 \%$ of bacteria, $2.3 \%$ of fungi, $0.7 \%$ of archaea and $4.4 \%$ of viridiplantae (green plants); 3) DNA from coal residue after one-month of bioconversion consisted of bacteria, fungi, archaea and viridiplantae in the percentage of 98.0\%, $0.04 \%, 0.09 \%$ and $1.83 \%$, respectively; and 4) DNA from the adapted consortium cultivated on coal after one-month was composed of $95.6 \%$ of bacteria, $1.4 \%$ of fungi, $1.6 \%$ of archaea and $1.4 \%$ of viridiplantae.

For the formation water, the $515 \mathrm{~F}$ assay revealed 231 bacterial species and 33 archaea at the species level. The $16 \mathrm{~F}$ and $86 \mathrm{~F}$ assay recovered 147 bacteria and 25 methanogen species, respectively. The difference lies in the fact that the $515 \mathrm{~F}$ assay provided a much more in-depth sequencing compared to the other two. However, the dominant species disclosed between the $515 \mathrm{~F}$ and $16 \mathrm{~F}$ assays for bacterial species and those between the $515 \mathrm{~F}$ and $86 \mathrm{~F}$ analyses for archaea were very similar. Hence, only results from the $515 \mathrm{~F}$ assay were reported for both the bacteria and archaea kingdom.

Among all of the bacteria identified in the original microbial community, the major populations were: Meniscus spp. (11.1\%), Syntrophus sp. (10.0\%), Ruminococcus spp. (8.1\%), Dasania spp. (4.7\%), Candidatus_solibacter spp. (4.4\%), Crocinitomix spp. (3.6\%), Desulfofustis spp. (3.5\%), Thermovirga spp. (3.5\%), Sulfurimonas spp. (3.4\%), Desulfuromusa spp. (3.4\%), Maritimimonas spp. (3.3\%), Alkaliflexus spp. (2.8\%), Desulfuromonas spp. (2.8\%), and Desulfotignum spp. (2.1\%) (Figure 3a). The genus of Meniscus is known to be aerotolerant and heterotrophic bacteria (Irgens, 1977). They can grow on a broad range of mono- and disaccharides provided the concentration of $\mathrm{CO}_{2}$ is more than $1 \%$. The Syntrophus genus includes anaerobic bacteria that are shown to catabolize benzoate and fatty acids in syntrophic 
association with hydrogen-using methanogens (Jackson et al., 1999; Mountfort et al., 1984). Ruminococcus spp. are generally found in rumen fluid and are featured by their capability to degrade cellulose and other plant-based polymers (Klieve et al., 2005; Koike and Kobayashi, 2001). Research on Dasania spp. is few. The only publication on a new species of Dasania described it as a nitrate reducer to nitrogen within the order of Pseudomonadales (Lee et al., 2007).Candidatus_solibacter spp. belongs to the phylum of Acidobacteria which are widespread in soils and sediments worldwide, and are abundant in many soils (Challacombe et al., 2011). Exact functions of this genus is unclear except they may be acidophilic based on their lineage.

Among the top 13 Genera, Desulfofustis spp., Desulfuromusa spp. and Desulfotignum spp. are related to dissimilatory sulfate reduction. For example, the Genus of Desulfuromusa spp. is categorized as obligately anaerobic, sulfate and Fe (III)-reducing bacteria (Liesack and Finster, 1994; Vandieken et al., 2006). They were picked by the next generation sequencing, but were not detected in clone libraries developed from samples collected from the same, although different part of the Illinois basin (Strąpoć et al., 2008). In addition, Sulfurimonas spp. which can oxidize sulfur to sulfate was also observed. Thus, in the coal mine where the formation water was sampled, sulfate reduction and oxidation is actively performed by different microbial strains. Among all identified archaea species in the original community, the dominant ones at the species level were: Methanobacteriaceae methanobacterium sp. (44.7\%); Methanobacterium subterraneum (38.7\%); Methanococcus maripaludis (5.8\%) Methanobacteriaceae spp. (2.2\%), and Methanocalculus pumilus (2.1\%) (Fig. 3b). Thus, the majority (89.8\%) of archaea belonged to the order of Methanobacteriales. The Methanobacteriales are generally hydrogenotrophic, using hydrogen to reduce $\mathrm{CO}_{2}$ to $\mathrm{CH}_{4}$. Formate, $\mathrm{CO}$ and secondary alcohols can also be used as electron donors by some members of this order for $\mathrm{CO}_{2}$ reduction (Bonin and Boone, 2006). 
Besides Methanobacteriales, the order of Methanococcales and Methanomicrobiales were 5.8\% and $3.6 \%$ of the total, respectively. Based on these results, enhancing methane production in situ may benefit from providing $\mathrm{H}_{2}$ and/or other electron donors to stimulate methanogenic activities.

Regarding the coal samples that were used in this study, it is surprising to identify green plant DNA. As shown in Fig. 4, the majority or 99.9\% of green plant DNA in the original coal belonged to Tracheophyta spinacia oleracea (Spinach). The Sphagnum rubellum (Red Peatmoss) DNA was $0.1 \%$. But for coal residue and the adapted microbial consortium, DNA from Zea mays (corn) and Red Peatmoss was present and had a larger representation compared to that in the original coal samples. Here, we hypothesized that all of these green plant DNA originated from the biomass that was the initial material for coal formation. As coal degradation took place in the microcosms, more DNA in coal was mobilized and showed up in the extracted samples. Although proving this hypothesis requires more investigations, it is interesting to get a glimpse of the origin of Illinois coal.

In addition to DNA from green plants, fungal DNA was also detected in the coal samples that we have used (Fig. 5). For untreated coals, DNA from Emericella variecolor (61.1\%), Cryptomyces maximus (20.4\%), Amylomyces rouxii (10.7\%), and Zygozyma arxii (7.8\%) was identified. For coal residue and the adapted consortium, however, different fungal DNA from Phoma herbarum (a fungal plant pathogen), Didymocrea sadasivanii (a filamentous fungus), Bimuria novae_zelandiae (isolated from barley field) and Byssochlamys nivea (an extremely heat resistant mold) were observed. Since the formation water had no fungal strains, the fungal DNA revealed in the adapted consortium must be from coals added to the microcosms. The presence of fungal DNA in the original coal samples could be from: 1) fungal strains initially associated with coal. During coal formation, some fungal DNA was preserved in the process; 2) fungal strains in 
air and water. As described above, the coal samples were intentionally exposed to air and water during storage to simulate mined out coals and coal wastes. The exact source of these DNA deserves further investigation. To explain the difference between DNA detected in the original coal and that in the coal residue/ adapted consortium, we hypothesized that: 1) during coal bioconversion, more DNA was mobilized as porosity of coal was increased; and 2) some DNA associated with the original coal was degraded by enzymes released from the mixed consortium. Again, proving this hypothesis demands further studies.

It is not surprising to find microorganisms that are associated with coal as they have been reported for subbituminous coals at Texas (Jones et al., 2010) and anthracite coal in a coal mine in Hubei, China (Wei et al., 2014). For the former, only bacteria species was identified. Cloning methanogens and sulfate-reducing bacteria was proven to be unsuccessful. For the latter, both bacteria and archaea were detected through pyrosequencing and quantified by real time PCR. The total population for each kingdom was estimated to be $10^{5}$ and $10^{4}$ cells/g coal, respectively. Methanogens were calculated as $10^{4}$ cells $/ g$ coal and $10^{5}$ cells $/ \mathrm{mL}$ of mine water.

In terms of coals used in this study, it contained 113 different bacterial species (Fig. 6a). The top species were Pseudomonas putida (35.1\%), Staphylococcus pasteuri (11.2\%), Acinetobacter septicus (4.3\%), Staphylococcus epidermidis (2.7\%), Luteipulveratus mongoliensis (2.6\%) and Ruminococcus torques (2.6\%). For the coal residue left after bioconversion, 109 species were detected (Fig. 6b). The major ones were: Pseudomonas putida (26.7\%), Erwinia pantoea dispersa (7.7\%), Pantoea agglomerans (6.0\%),

Candidatus_chloracidobacterium spp.(3.5\%), Rubellimicrobium spp. (3.2\%), Methylobacterium adhaesivum (3.2\%), Pantoea spp. (3.1\%), Methylobacterium aquaticum (3.0\%), Staphylococcus pasteuri (2.9\%), Clostridium bifermentans (2.6\%), Pseudomonas oryzihabitans (2.3\%), and 
Massilia spp. (1.8\%). With regard to the adapted consortium, a total of 185 species were identified (Fig. 6c). The abundant ones were: Clostridium bifermentans (15.1\%), Massilia spp. (11.1\%), Pseudomonas putida (11.1\%), Proteiniphilum spp. (6.5\%), Pseudomonas stutzeri (6.4\%), Shewanella algae (5.7\%), Arcobacter spp. (5.3\%), Gelria spp. (2.8\%), Ruminococcus spp. (2.2\%), Methylobacterium aquaticum (2.0\%), Tindallia texcoconensis (2.0\%), and Syntrophomonas spp. (1.9\%).

Comparing bacterial species in the original formation water and those in the adapted consortium, a dramatic difference was observed. Among the top ten species in the formation water, except Rumicoccus spp. whose percentage decreased from $8.1 \%$ to $2.8 \%$ in the adapted consortium, the other top nine bacterial species originally in the formation water became minor ones. In contrast, some less prevalent species became dominant in the adapted consortium. However, since they were present in both the formation water and in the coal samples, it is not clear at this point where exactly they came from. Undoubtedly, these species, under the experimental conditions adopted for this study, might be more competitive than those predominant ones initially in the formation water.

The class of Clostridia was found to dominate in an enrichment culture derived from formation water collected from subbituminous coal beds in western Canada (Penner et al., 2010). It was also reported to prevail in yeast extract amended CBM well water samples (Green et al., 2008; Li et al., 2008). Clostridium bifermentans was identified as hydrogen producers when grown on wastewater sludge (Wang et al., 2003). The genus Massilia belongs to the family of Oxalobacteraceae and class of Betaproteobacteria. Research on this genus is not much. But, novel species, such as Massilia tieshanensis isolated from mining soil (Du et al., 2012) and Massilia kyonggiensis isolated from forest soil in Korea (Kim, 2014) were demonstrated to have 
no growth under anaerobic conditions (Du et al., 2012). Apparently, the strains in the adapted consortium were different from those isolated and studied. Similarly, identification of $P$. putida in the adapted consortium contradicts the common recognition that this species includes strictly aerobic bacteria (Sohn et al., 2010). Therefore, the adapted consortium may contain some novel strains that have not been investigated and reported so far. Apart from these controversies, Proteiniphilum spp. are reported as obligately anaerobic strains. For two Proteiniphilum acetatigenes, the major fermentation products from yeast extract and peptone are acetic acid and propionic acid (Chen and Dong, 2005). P. stutzeri, also detected in a Canadian coal mine, was identified as a denitrifier (Penner et al., 2010).

In terms of archaea identification, the coal samples contained only one species: Methanobrevibacter spp. For the coal residues, two species were detected: Methanobrevibacter arboriphilus (51.7\%) and Methanobacterium bryantii (48.3\%). For the adapted consortium, a total of nine species were observed (Fig. 7): Methanocalculus pumilus (43.9\%), Methanocalculus taiwanensis (42.7\%), Methanosarcina lacustris (7.1\%), Methanomicrobium spp. (3.5\%), Halobacterium spp. (1.0\%), Methanosaeta spp. (0.9\%), Thermoplasma spp. (0.5\%), Methanocalculus halotolerans (0.4\%), and Methanobacterium ferruginis $(0.01 \%)$. Thus, in the adapted consortium, the majority of archaea belonged to the Methanocalculus genus and the Methanomicrobiales order. Again, comparing with archaea strains initially in the formation water, the minor order of Methanomicrobiales became the dominant one $(90.4 \%)$ while the major order of Methanobacteriales turned to be the minor one $(0.01 \%)$.

Both pure strains of Methanocalculus pumilus and Methanocalculus taiwanensis have been isolated and studied. The former was isolated from a waste-disposal site containing high concentrations of metals (Mori et al., 2000) and the latter was isolated from an estuarine 
environment in Taiwan (Lai et al., 2002). Belonging to the same genus of Methanocalculus, both strains can perform methanogenesis from formate and $\mathrm{CO}_{2} / \mathrm{H}_{2}$. Acetate was required for cell growth, but this substrate cannot be converted to methane. Knowing the presence of either these two methanogens or other strains that are similar to these two in the adapted consortium will assist us in designing strategies to maximize methane production from coal.

\subsection{Methane yield from coal}

To evaluate whether microorganisms in the formation water can convert coal to methane $e x$ situ, we first tested methane yield with the addition of two different media. As shown in Fig. 8a, compared with the control (no medium which contained only the formation water and concentrated microbial cells, medium \#1 which was the Tanner medium specifically for strict anaerobes, did not have much effect at two concentrations studied: $20 \%$ and 50\%. Medium $\# 2$, however, demonstrated increased methane production with increased medium concentration, from $20 \%, 50 \%$ to $100 \%$. For the microcosms with $100 \%$ medium \#2, the methane yield was 84 $\mathrm{ft}^{3} /$ ton of coal, which translated to a methane production rate of $1.3 \mathrm{ft}^{3} /$ ton/day in 65 days. For this study, we stopped the experiment at day 65 since methane production rate $\left(\mathrm{ft}^{3} /\right.$ ton-day) between day 30 and 65 was lower than that during the first 30 days. This could be due to many reasons, such as: inhibitory gas and liquid compounds in the reactors, nutrient depletion, etc. Currently, we are conducting comprehensive experiments to understand the coal bioconversion process and increase the methane production rate. Although methane yield was all different under different conditions, there was no statistically significant difference in terms of $\mathrm{CO}_{2}$ concentration in all of the microcosms (Fig. 8b). The presence of $\mathrm{CO}_{2}$ indicated that the microbial community was active even though for some, no or little methane was detected.

To test whether purging with $\mathrm{N}_{2}$ was necessary after the microcosms were just established, 
we used 100\% medium \#2 and acclimated cells from our first experiment to start the second round of testing. For two microcosms, purging was conducted for $30 \mathrm{~min}$. For another two, no purging was performed. This time, we observed must faster generation of $\mathrm{CH}_{4}$ (Fig. 9a) and $\mathrm{CO}_{2}$ (Fig. 9b). With regard to methane production rate, the acclimated cells gave $5.6 \mathrm{ft}^{3} /$ ton/day during the first 20 days. In terms of $\mathrm{CO}_{2}$, the release rate in the first 10 days was $6.14 \mathrm{ft}^{3} /$ ton/day, which was much higher than $0.24 \mathrm{ft}^{3} /$ ton/day observed during the first experiment. Regarding with or without nitrogen purging, between these two setups, there was no statistically significant difference in terms of yield of $\mathrm{CO}_{2}$ and $\mathrm{CH}_{4}$, which suggests that the microcosms can be initiated under a relaxed, and not strictly anaerobic condition. In other words, the microbial consortium is highly robust and nitrogen purging is not needed. Since $\mathrm{CO}_{2}$ can be reduced to $\mathrm{CH}_{4}$ if hydrogen is present, the high concentration of this gas indicated that the cultures might be hydrogenlimited.

The approach of converting coal to methane through biological processes has been explored by several research groups. The majority of studies on this aspect have been conducted in a strictly anaerobic environment with coal and the microbial community handled in a glove box (Green et al., 2008; Harding et al., 1993; Jones et al., 2010; Papendick et al., 2011). The only exception is the one reported by Opara et al. (Opara et al., 2012) where both coal and the microbial inoculum were exposed to air during sample collection, transfer and handling. But even with air exposure, the methane production rate of $73.1 \mathrm{ft}^{3} /$ ton/day was the highest among bituminous coals. This could be due to the smallest particle size $(<74 \mathrm{um})$ among all studies reported or owing to the robustness of the microbial community collected from a waste coal environment.

For this study, we took a similar strategy of evaluating methane production from coal 
under a relaxed anoxic condition. We strongly agree with the statement given by the Opara et al. (Opara et al., 2012) that an aerotolerant microbial consortium is a crucial element for large scale application of bioconversion of coal to methane. The statement is true for two scenarios: 1) injection of a microbial consortium to coal mines where indigenous microbial community is either unable or has limited capability to produce methane from coal; and 2) conversion of mined out coal or coal waste to methane ex situ.

As discussed above, in this study, we obtained a methane production rate of $5.6 \mathrm{ft}^{3} / \mathrm{ton} /$ day and a methane yield of $111 \mathrm{ft}^{3} /$ ton in 20 days. This production rate is higher than $2.1 \mathrm{ft}^{3} /$ ton/day from low volatile bituminous (Fallgren et al., 2013), $2.7 \mathrm{ft}^{3} /$ ton/day from subbituminous B coals (Green et al., 2008), and $0.8 \mathrm{ft}^{3} /$ ton/day from subbituminous coals (Jones et al., 2010). However, it is lower than $30 \mathrm{ft}^{3} /$ ton/day reported for subbituminous coals from Australia (Papendick et al., 2011). This high methane production rate was obtained at $37^{\circ} \mathrm{C}$ and with mixing at $50 \mathrm{rpm}$.

Overall, we have proven that the approach of converting coal to methane ex situ is feasible. Further increasing methane yield may benefit from evaluating other parameters, such as, temperature, $\mathrm{pH}$, coal particle size, mixing and the presence of solvent and/or surfactant, etc.

\section{Acknowledgements}

This material is based upon work supported by the Illinois Clean Coal Institute under the Award Number of 13/4C-2 and the Department of Energy under Award Number DEFE0024126.

\section{Disclaimer}

This report was prepared as an account of work sponsored by an agency of the United States 
Government. Neither the United States Government nor any agency thereof, nor any of their employees, makes any warranty, express or implied, or assumes any legal liability or responsibility for the accuracy, completeness, or usefulness of any information, apparatus, product, or process disclosed, or represents that its use would not infringe privately owned rights. Reference herein to any specific commercial product, process, or service by trade name, trademark, manufacturer, or otherwise does not necessarily constitute or imply its endorsement, recommendation, or favoring by the United States Government or any agency thereof. The views and opinions of authors expressed herein do not necessarily state or reflect those of the United States Government or any agency thereof."

\section{Figure captains:}

Fig. 1: Location of the site (red star) where coal samples were collected. Adapted from Korose and Elrick, 2010.

Fig. 2: Distribution of different kingdoms for DNA extracted from the original community, coal samples, coal residue and the adapted consortium.

Fig. 3: Diversity of microbes in the formation water. a: bacterial species; b: archaea species. Fig. 4: Distribution of Viridiplantae (green plant DNA) for coal samples, coal residue and the adapted consortium.

Fig. 5: Distribution of fungal DNA for coal samples, coal residue and the adapted consortium. Fig. 6: Diversity of bacterial species in different samples. a: coal samples used for this study; b: coal residue after bioconversion for 30-days; c: adapted consortium.

Fig. 7: Diversity of archaea species in the adapted consortium.

Fig. 8: Gas production from microcosms containing different nutrient supplementation. a: 
methane; b: $\mathrm{CO}_{2}$.

Fig. 9: Effect of purging on gas production from microcosms. a: methane; b: $\mathrm{CO}_{2}$.

Table 1: Ultimate and proximate analysis of the coal samples used.

\section{References:}

Agyarko, L.B., Mansoori, G.A., 2013. A review of non-renewable energy options in Illinois.

International Journal of Oil, Gas and Coal Technology 6, 288-347.

Ayers, W.B., 2002. Coalbed gas systems, resources, and production and a review of contrasting cases from the San Juan and powder river basins. American Association of Petroleum Geologists Bulletin 86, 1853-1890.

Berman, A.E., 2010. Shale gas-Abundance or mirage? Why the Marcellus Shale will disappoint expectations. Energy Bulletin. 
Berman, A.E., Pittinger, L., 2011. US shale gas: less abundance, higher cost. The Oil Drum: http://www. theoildrum. com/node/8212.

Bonin, A.S., Boone, D.R., 2006. The order methanobacteriales, The Prokaryotes. Springer, pp. 231-243.

Caporaso, J.G., Lauber, C.L., Walters, W.A., Berg-Lyons, D., Lozupone, C.A., Turnbaugh, P.J., Fierer, N., Knight, R., 2011. Global patterns of 16 S rRNA diversity at a depth of millions of sequences per sample. Proceedings of the National Academy of Sciences 108, 4516-4522.

Challacombe, J.F., Eichorst, S.A., Hauser, L., Land, M., Xie, G., Kuske, C.R., 2011. Biological consequences of ancient gene acquisition and duplication in the large genome of Candidatus Solibacter usitatus Ellin6076. PloS one 6, e24882.

Chen, S., Dong, X., 2005. Proteiniphilum acetatigenes gen. nov., sp. nov., from a UASB reactor treating brewery wastewater. International Journal of Systematic and Evolutionary Microbiology $55,2257-2261$.

Chen, S.S., Khan, L., Rostam-Abadi, M., 2003. A novel fine coal dewatering process with integrated biomass utilization. ICCI final technical report.

DeSantis, T.Z., Hugenholtz, P., Larsen, N., Rojas, M., Brodie, E.L., Keller, K., Huber, T., Dalevi, D., Hu, P., Andersen, G.L., 2006. Greengenes, a chimera-checked 16S rRNA gene database and workbench compatible with ARB. Applied and Environmental Microbiology 72, 5069-5072.

Dowd, S.E., Callaway, T.R., Wolcott, R.D., Sun, Y., McKeehan, T., Hagevoort, R.G., Edrington, T.S., 2008. Evaluation of the bacterial diversity in the feces of cattle using 16S rDNA bacterial tag-encoded FLX amplicon pyrosequencing (bTEFAP). BMC Microbiology 8, 125. 
Du, Y., Yu, X., Wang, G., 2012. Massilia tieshanensis sp. nov., isolated from mining soil. International Journal of Systematic and Evolutionary Microbiology 62, 2356-2362.

Edgar, R.C., 2010. Search and clustering orders of magnitude faster than BLAST. Bioinformatics $26,2460-2461$.

EIA (Enery Information Administration) http://www.eia.gov/totalenergy/data/annual/showtext.cfm?t=ptb0408.

Faiz, M., Hendry, P., 2006. Significance of microbial activity in Australian coal bed methane reservoirs - A review. Bulletin of Canadian Petroleum Geology 54, 261-272.

Fallgren, P.H., Jin, S., Zeng, C., Ren, Z., Lu, A., Colberg, P.J.S., 2013. Comparison of coal rank for enhanced biogenic natural gas production. International Journal of Coal Geology 115, 92-96. Flores, R.M., Rice, C.A., Stricker, G.D., Warden, A., Ellis, M.S., 2008. Methanogenic pathways of coal-bed gas in the Powder River Basin, United States: The geologic factor. International Journal of Coal Geology 76, 52-75.

Green, M.S., Flanegan, K.C., Gilcrease, P.C., 2008. Characterization of a methanogenic consortium enriched from a coalbed methane well in the Powder River Basin, USA. International Journal of Coal Geology 76, 34-45.

Harding, R., Czarnecki, S., Isbister, J., Barik, S., 1993. Biogasification of low-rank coal. Electric Power Research Inst., Palo Alto, CA (United States); ARCTECH, Inc., Chantilly, VA (United States).

Howarth, R.W., Santoro, R., Ingraffea, A., 2011. Methane and the greenhouse-gas footprint of natural gas from shale formations. Climatic Change 106, 679-690.

Irgens, R.L., 1977. Meniscus, a new genus of aerotolerant, gas-vacuolated bacteria. International Journal of Systematic Bacteriology 27, 38-43. 
Jackson, B.E., Bhupathiraju, V.K., Tanner, R.S., Woese, C.R., McInerney, M.J., 1999.

Syntrophus aciditrophicus sp. nov., a new anaerobic bacterium that degrades fatty acids and benzoate in syntrophic association with hydrogen-using microorganisms. Archives of Microbiology 171, 107-114.

Jones, E.J., Voytek, M.A., Corum, M.D., Orem, W.H., 2010. Stimulation of methane generation from nonproductive coal by addition of nutrients or a microbial consortium. Applied and Environmental Microbiology 76, 7013-7022.

Kim, J., 2014. Massilia kyonggiensis sp. nov., isolated from forest soil in Korea. Journal of Microbiology 52, 378-383.

Klieve, A.V., Yokoyama, M.T., Forster, R.J., Ouwerkerk, D., Bain, P.A., Mawhinney, E.L., 2005. Naturally occurring DNA transfer system associated with membrane vesicles in cellulolytic Ruminococcus spp. of ruminal origin. Applied and Environmental Microbiology 71, 4248-4253.

Koike, S., Kobayashi, Y., 2001. Development and use of competitive PCR assays for the rumen cellulolytic bacteria: Fibrobacter succinogenes, Ruminococcus albus and Ruminococcus flavefaciens. FEMS Microbiology Letters 204, 361-366.

Korose, C. P., Elrick, S. D. 2010. Coal geology of Illinois. Keystone Coal Industry Manual, 456467.

Lai, M.-C., Chen, S.-C., Shu, C.-M., Chiou, M.-S., Wang, C.-C., Chuang, M.-J., Hong, T.-Y., Liu, C.-C., Lai, L.-J., Hua, J.J., 2002. Methanocalculus taiwanensis sp. nov., isolated from an estuarine environment. International Journal of Systematic and Evolutionary Microbiology 52, 1799-1806. 
Lee, Y.K., Hong, S.G., Cho, H.H., Cho, K.H., Lee, H.K., 2007. Dasania marina gen. nov., sp. nov., of the order Pseudomonadales, isolated from Arctic marine sediment. Journal of Microbiology-Seoul, 45, 505.

Li, D., Hendry, P., Faiz, M., 2008. A survey of the microbial populations in some Australian coalbed methane reservoirs. International Journal of Coal Geology 76, 14-24.

Liesack, W., Finster, K., 1994. Phylogenetic analysis of five strains of gram-negative, obligately anaerobic, sulfur-reducing bacteria and description of Desulfuromusa gen. nov., including Desulfuromusa kysingii sp. nov., Desulfuromusa bakii sp. nov., and Desulfuromusa succinoxidans sp. nov. International Journal of Systematic Bacteriology 44, 753-758. McGlade, C., Speirs, J., Sorrell, S., 2013. Unconventional gas - A review of regional and global resource estimates. Energy 55, 571-584.

Mori, K., Yamamoto, H., Kamagata, Y., Hatsu, M., Takamizawa, K., 2000. Methanocalculus pumilus sp. nov., a heavy-metal-tolerant methanogen isolated from a waste-disposal site. International Journal of Systematic and Evolutionary Microbiology 50, 1723-1729. Mountfort, D., Brulla, W., Krumholz, L.R., Bryant, M., 1984. Syntrophus buswellii gen. nov., sp. nov.: a benzoate catabolizer from methanogenic ecosystems. International Journal of Systematic Bacteriology 34, 216-217.

Opara, A., Adams, D., Free, M., McLennan, J., Hamilton, J., 2012. Microbial production of methane and carbon dioxide from lignite, bituminous coal, and coal waste materials. International Journal of Coal Geology 96, 1-8.

Papendick, S.L., Downs, K.R., Vo, K.D., Hamilton, S.K., Dawson, G.K., Golding, S.D., Gilcrease, P.C., 2011. Biogenic methane potential for Surat Basin, Queensland coal seams. International Journal of Coal Geology 88, 123-134. 
Penner, T.J., Foght, J.M., Budwill, K., 2010. Microbial diversity of western Canadian subsurface coal beds and methanogenic coal enrichment cultures. International Journal of Coal Geology 82, 81-93.

Scott, A.R., Kaiser, W.R., Ayers Jr, W.B., 1994. Thermogenic and secondary biogenic gases, San Juan Basin, Colorado and New Mexico-Implications for coalbed gas producibility. AAPG Bulletin-American Association of Petroleum Geologists 78, 1186-1209.

Sohn, S.B., Kim, T.Y., Park, J.M., Lee, S.Y., 2010. In silico genome-scale metabolic analysis of Pseudomonas putida KT2440 for polyhydroxyalkanoate synthesis, degradation of aromatics and anaerobic survival. Biotechnology Journal 5, 739-750.

Strąpoć, D., Picardal, F.W., Turich, C., Schaperdoth, I., Macalady, J.L., Lipp, J.S., Lin, Y.-S., Ertefai, T.F., Schubotz, F., Hinrichs, K.-U., 2008. Methane-producing microbial community in a coal bed of the Illinois Basin. Applied and Environmental Microbiology 74, 2424-2432.

Tanner, R.S., Hurst, C., Crawford, R., Garland, J., Lipson, D., Mills, A., Stetzenbach, L., 2007. Cultivation of bacteria and fungi. Manual of Environmental Microbiology, 69-78.

Tillman, D.A., Harding, N.S., 2004. Fuels of opportunity. Characteristics and Uses in Combustion Systems. Elsevier, Kidlington, U.K, pp. 89-128.

Ulrich, G., Bower, S., 2008. Active methanogenesis and acetate utilization in Powder River Basin coals, United States. International Journal of Coal Geology 76, 25-33.

Vandieken, V., Mußmann, M., Niemann, H., Jørgensen, B.B., 2006. Desulfuromonas svalbardensis sp. nov. and Desulfuromusa ferrireducens sp. nov., psychrophilic, Fe (III)reducing bacteria isolated from Arctic sediments, Svalbard. International journal of systematic and evolutionary microbiology 56, 1133-1139. 
Wang, C., Chang, C., Chu, C., Lee, D., Chang, B.-V., Liao, C., 2003. Producing hydrogen from wastewater sludge by Clostridium bifermentans. Journal of Biotechnology 102, 83-92.

Wei, M., Yu, Z., Jiang, Z., Zhang, H., 2014. Microbial diversity and biogenic methane potential of a thermogenic-gas coal mine. International Journal of Coal Geology 134-135, 96-107. 


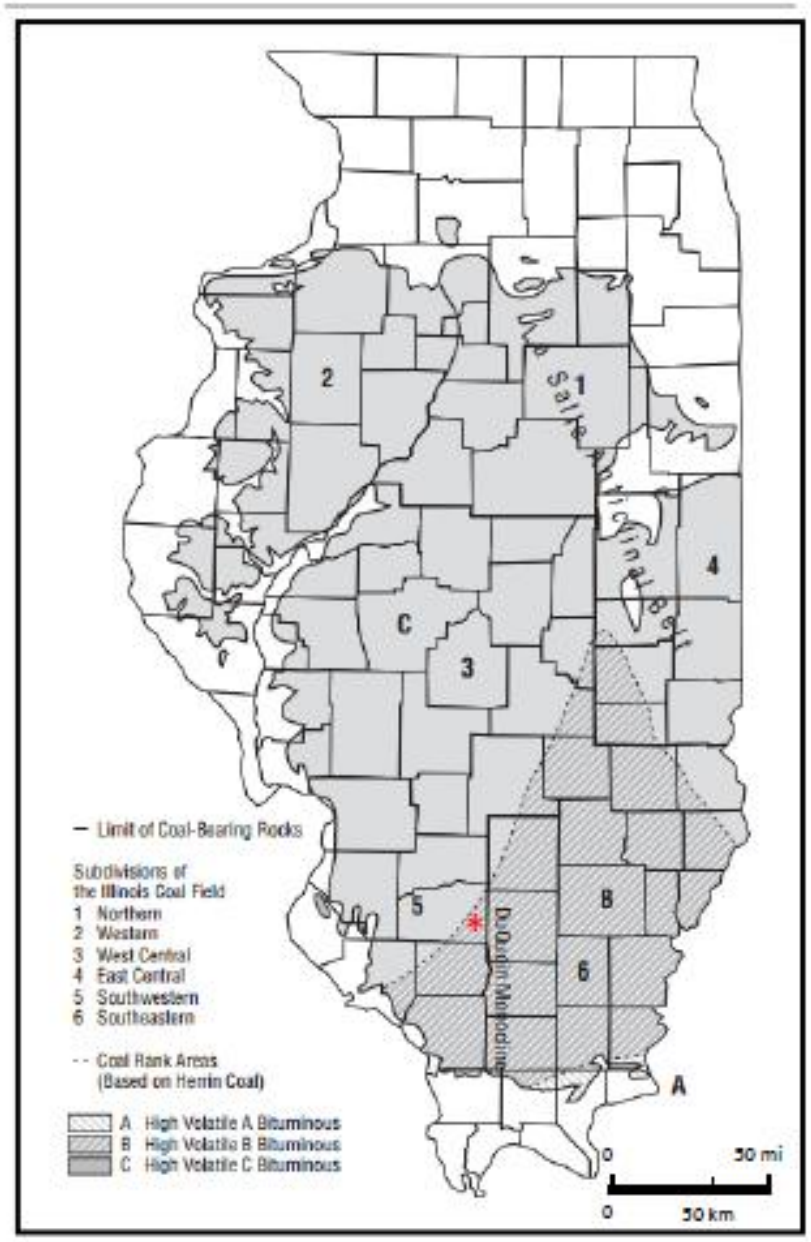

Figure 1 


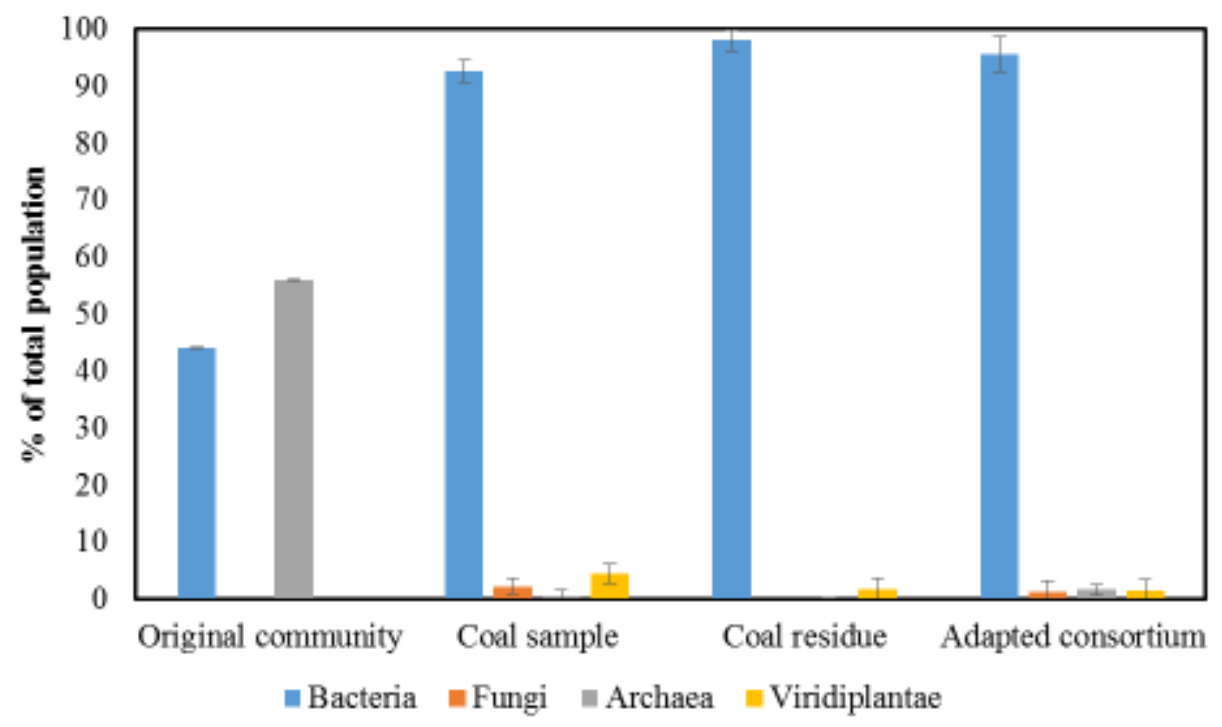

Figure 2 


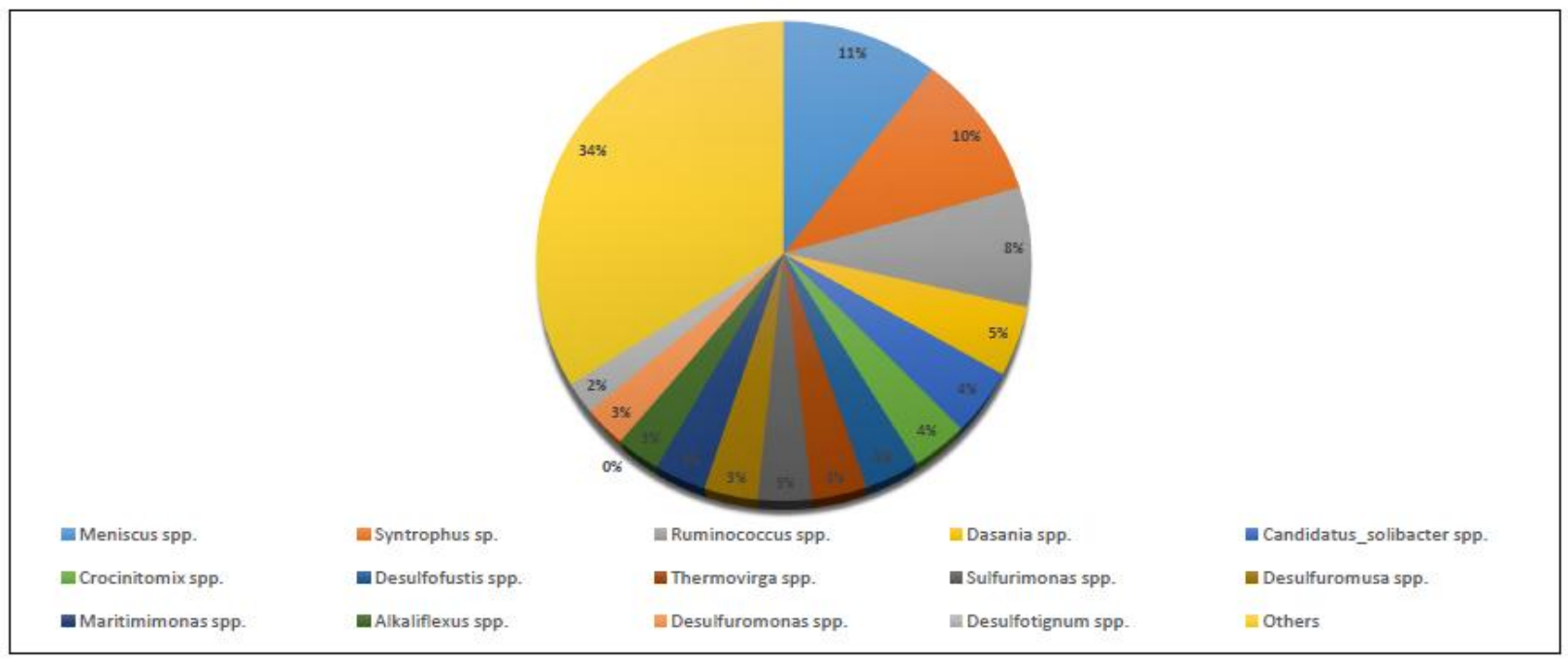

Figure $3 \mathrm{a}$ 


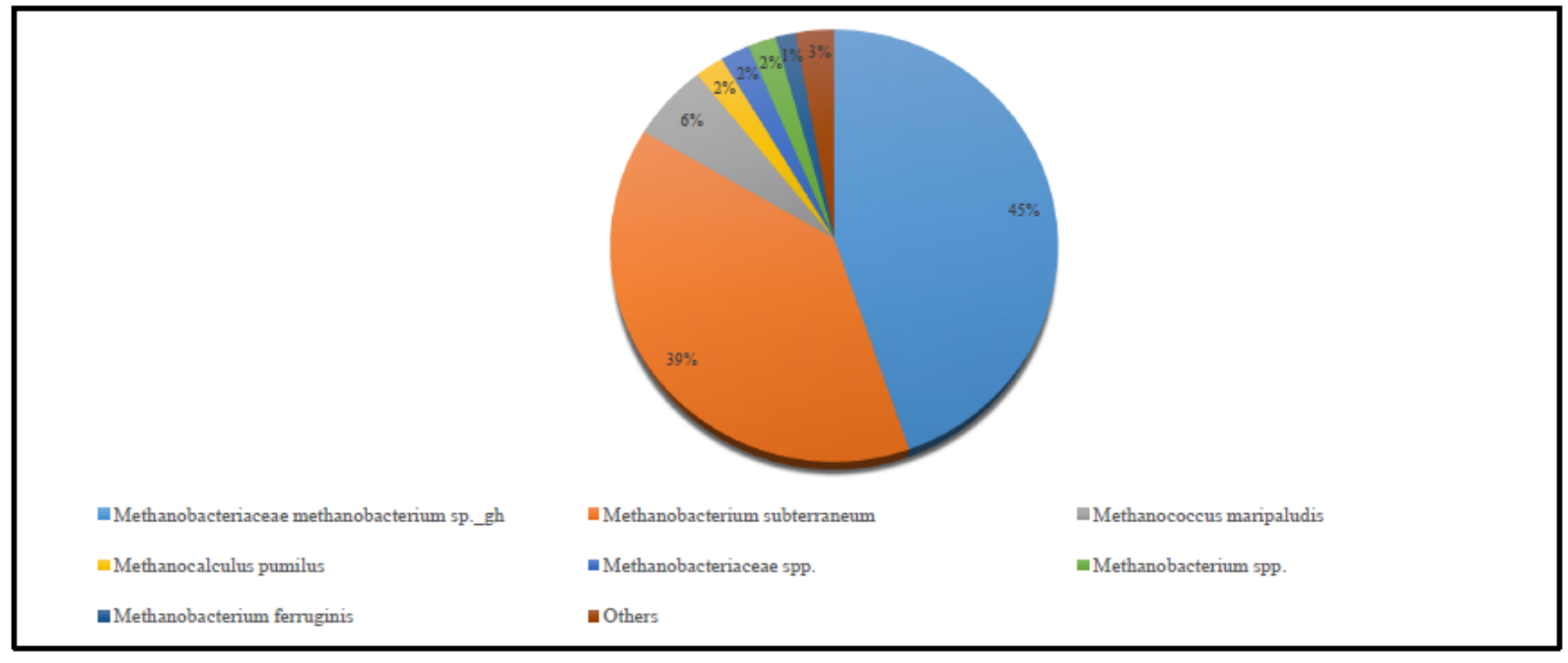

Figure $3 b$ 


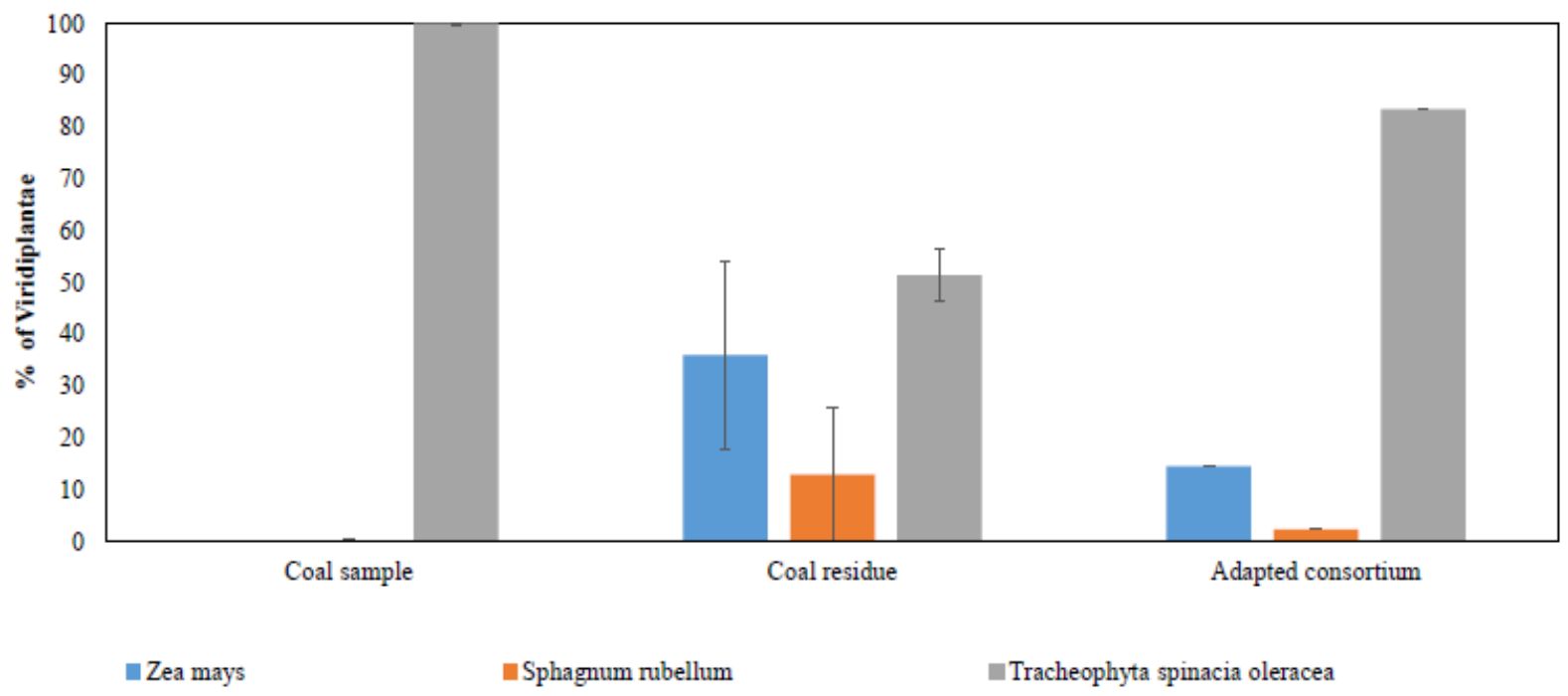

Figure 4 


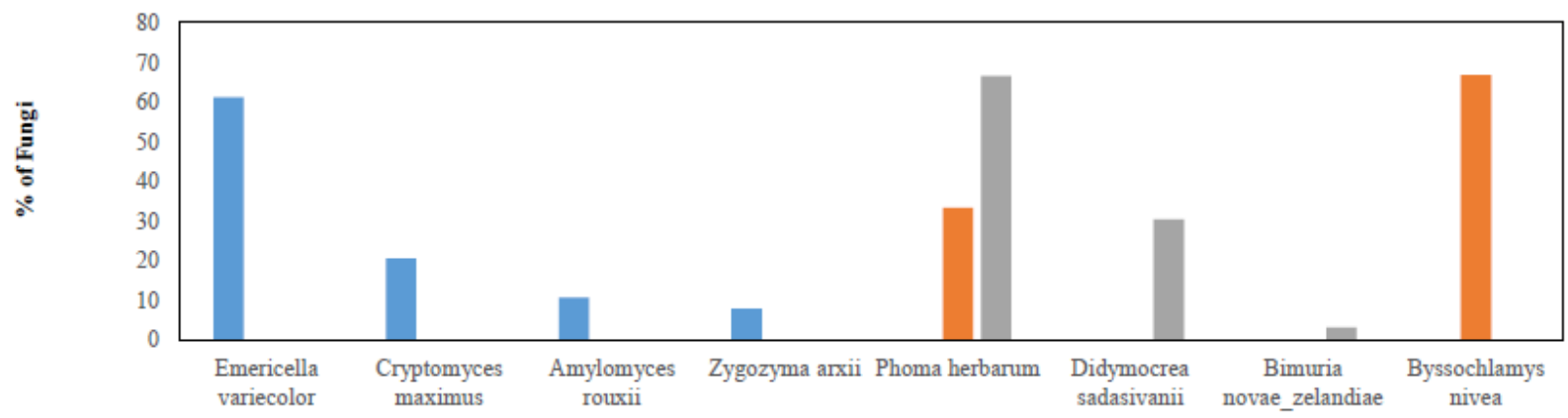

nCoal sample $\quad$ Coal residue Adapted consortium

Figure 5 


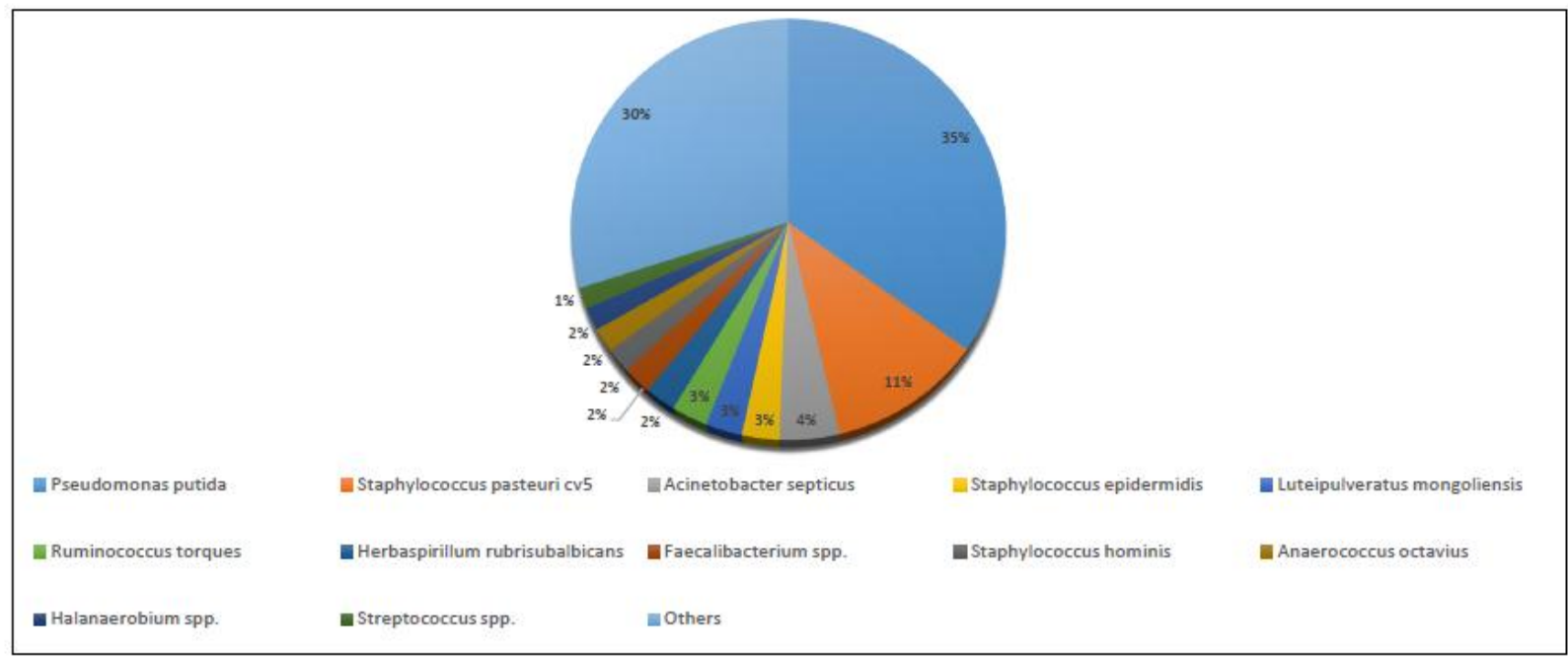

Figure 6a 


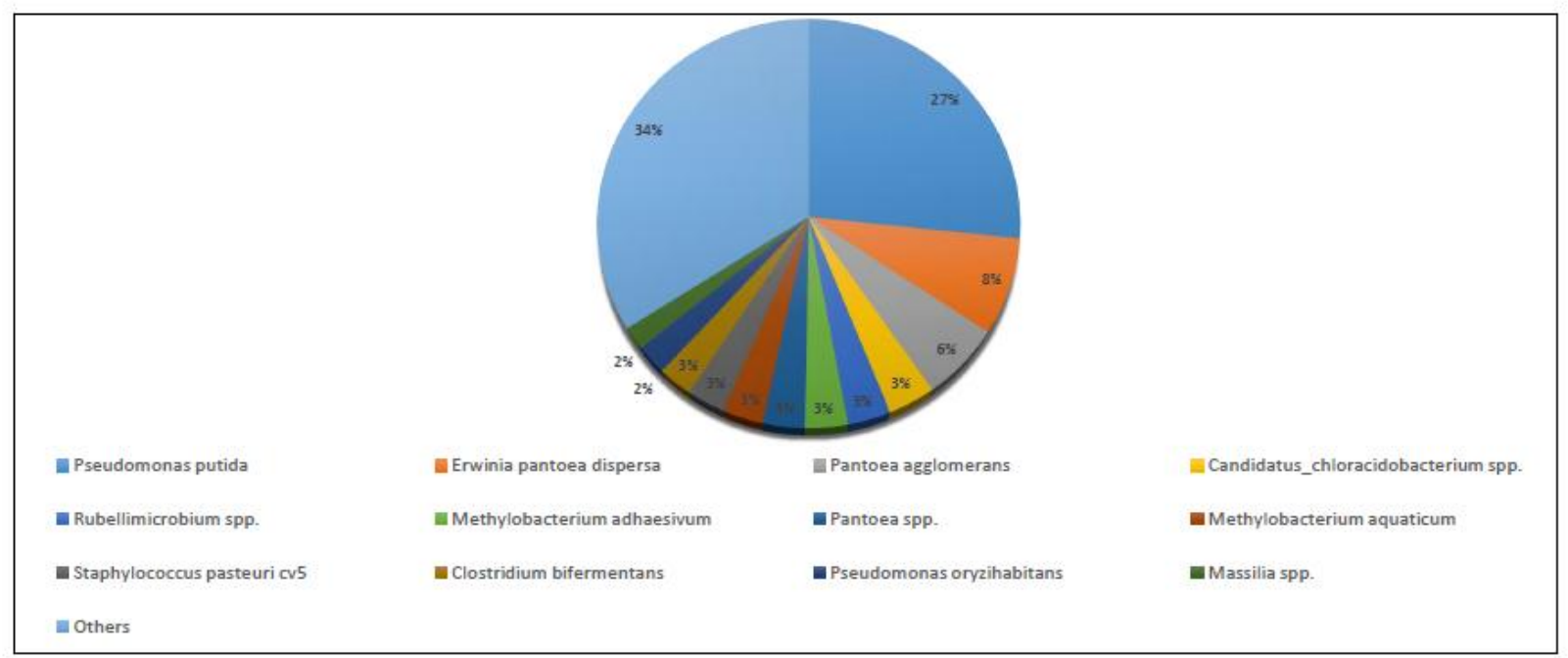

Figure $6 b$ 


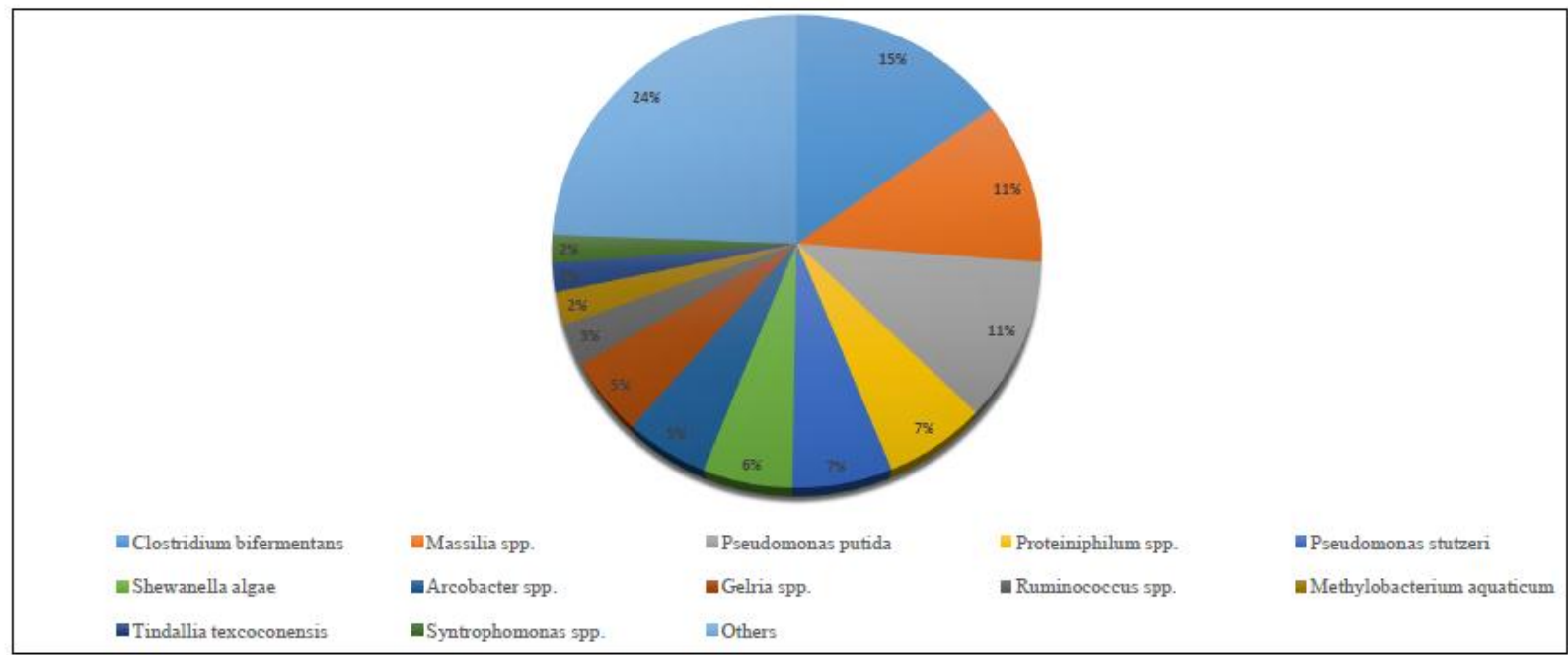

Figure 6c 


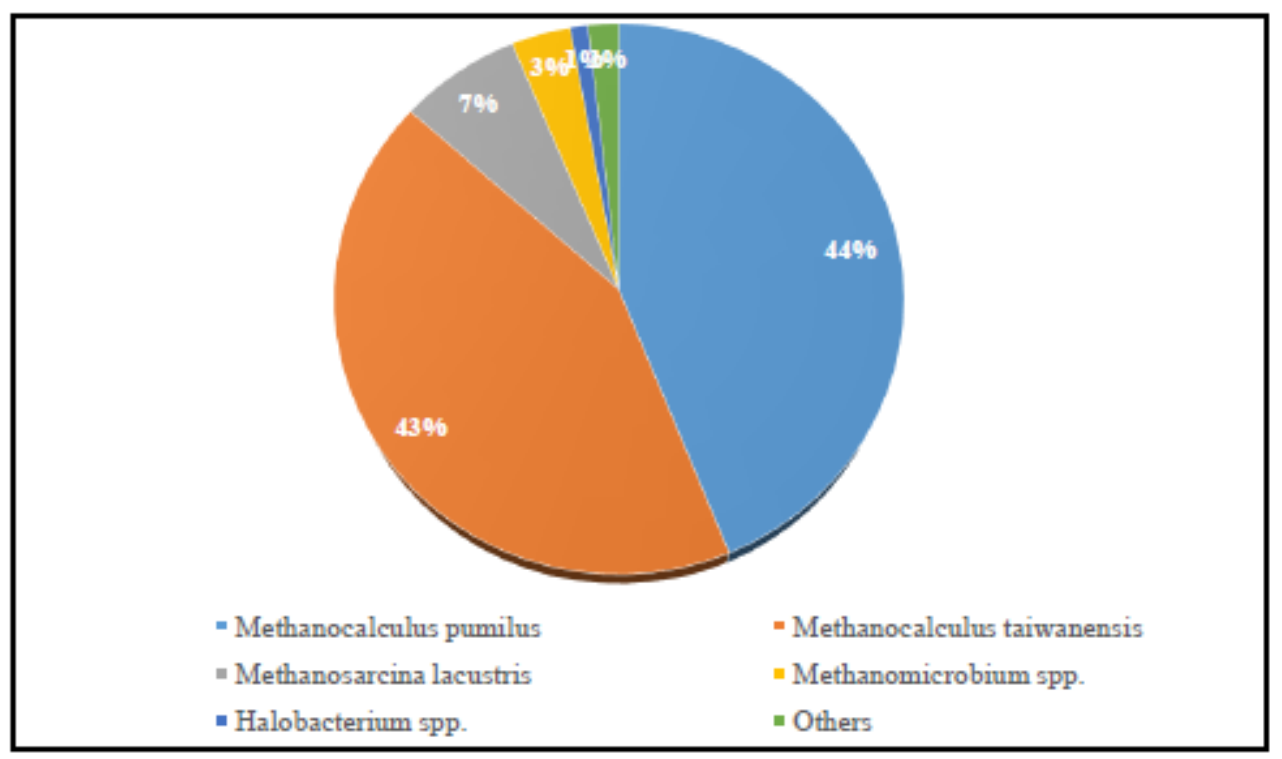

Figure 7 


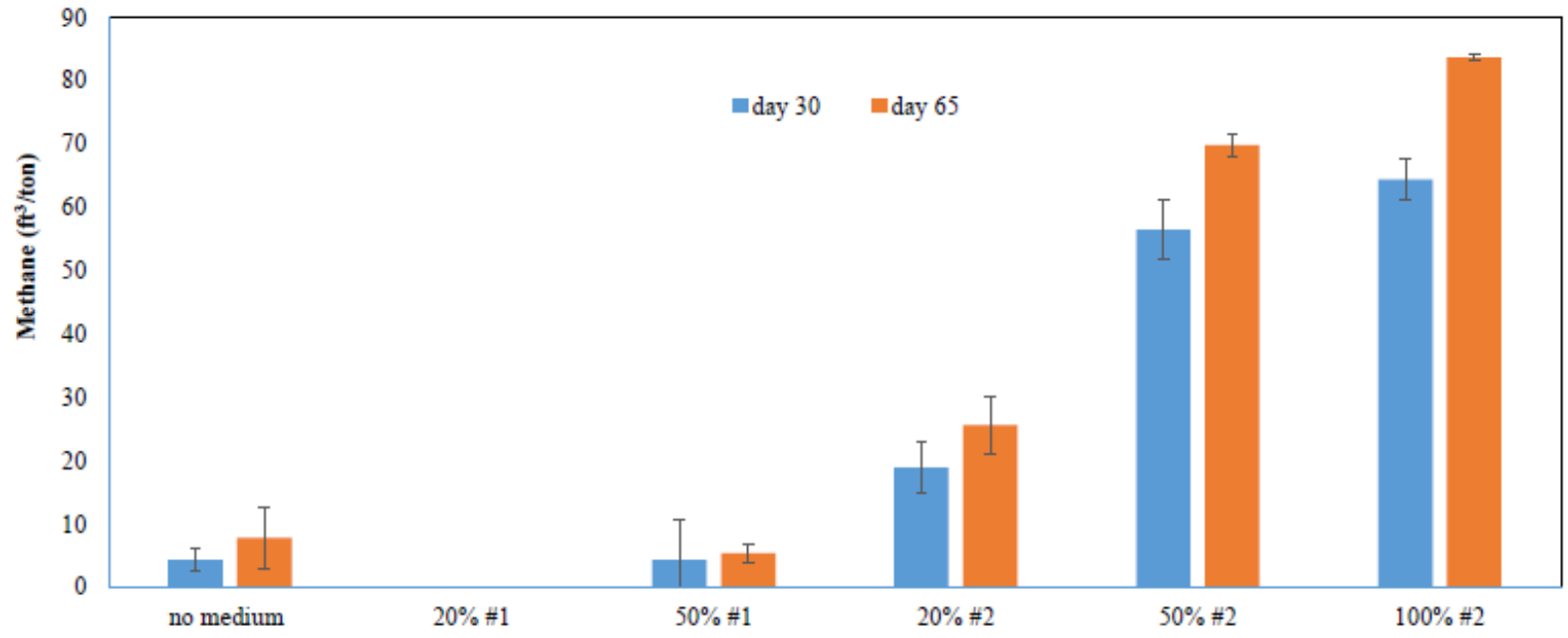

Figure 8a 


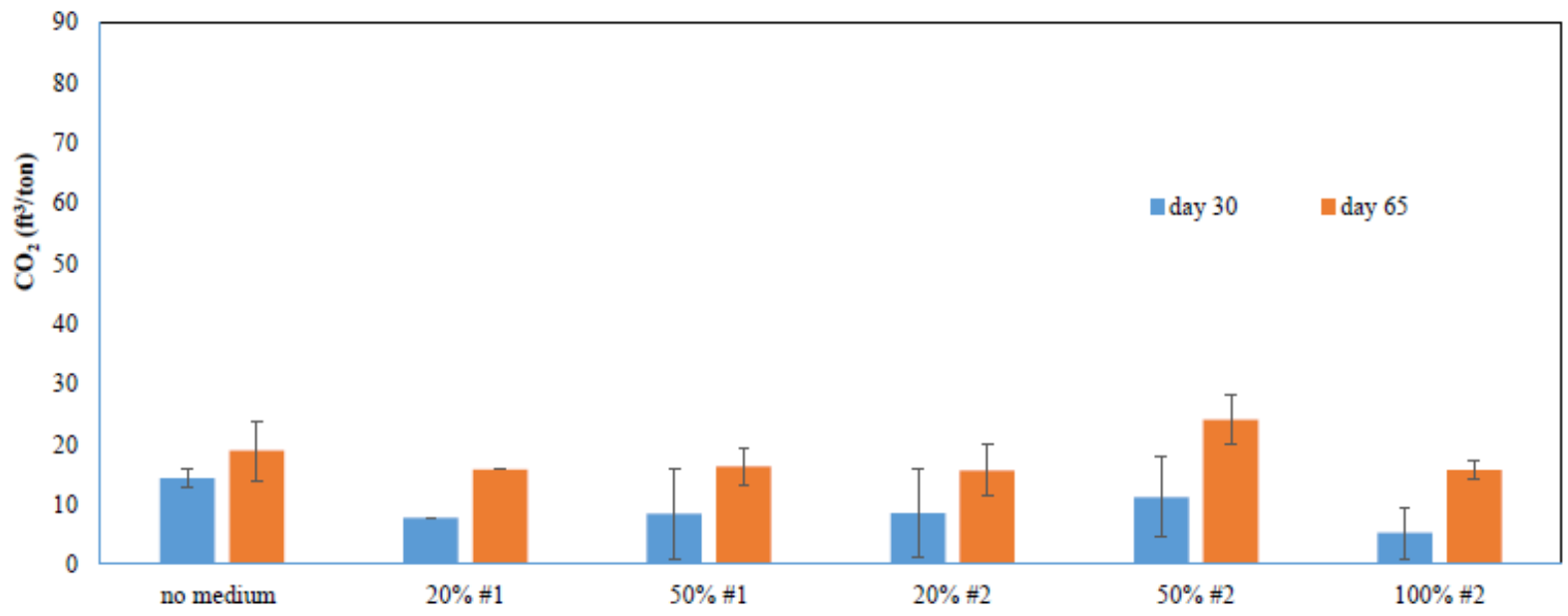

Figure $8 b$ 


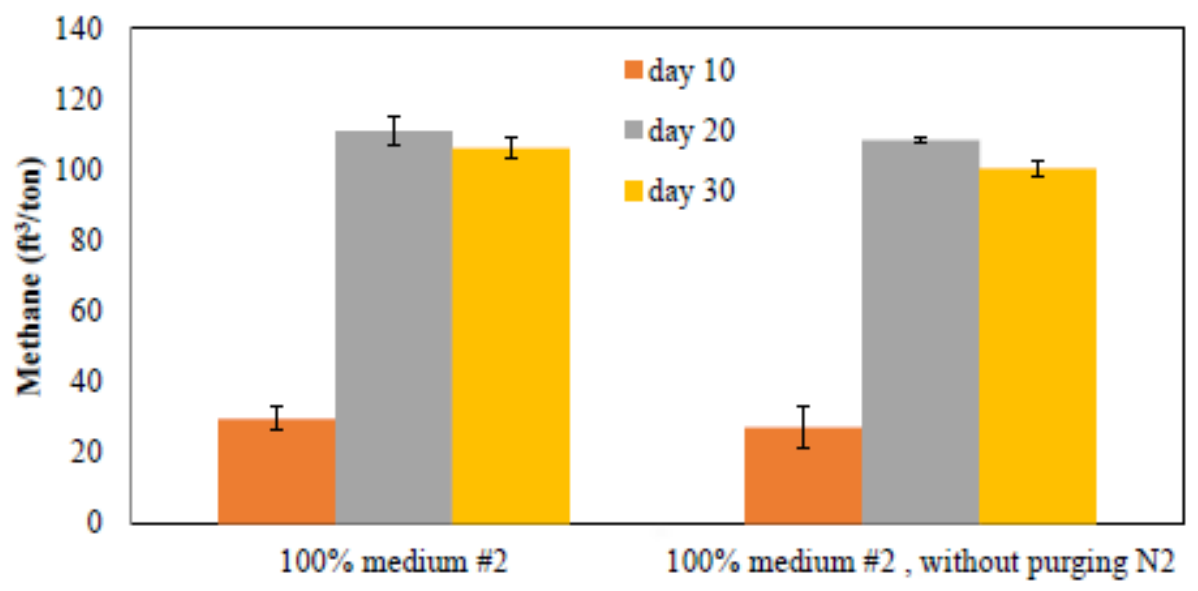

Figure 9a 


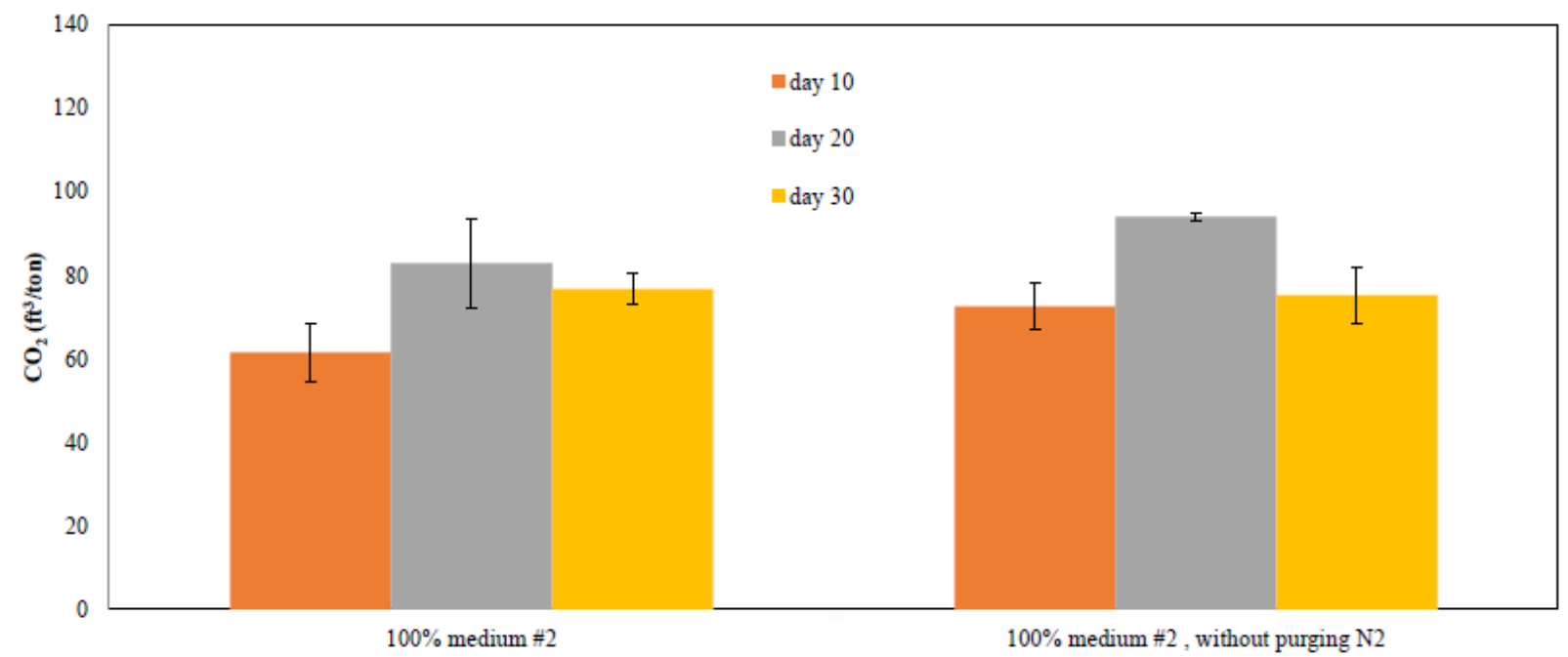

Figure 9b 
Table 1: Ultimate and proximate analysis of the coal samples used.

\begin{tabular}{rc} 
Parameter & Average \pm STDEV $(\%)$ \\
\hline \hline Ultimate analysis (dry basis) & \\
Carbon & $70.07 \pm 0.36$ \\
Nitrogen & $1.39 \pm 0.01$ \\
Hydrogen & $5.21 \pm 0.03$ \\
Sulfur & $0.63 \pm 0.03$ \\
Oxygen & $15.41 \pm 0.20$ \\
Proximate analysis (dry basis) & \\
Ash & $7.50 \pm 0.05$ \\
Volatile matter & $49.93 \pm 0.18$ \\
Fixed carbon & $42.58 \pm 0.17$ \\
Heating value (BTU/lb) & $12547.50 \pm 36.06$ \\
\hline
\end{tabular}

